\title{
Influence of the Internet on Young People as a Problem of Criminology Science
}

\author{
Gauhar Rustembekovna Rustemova ${ }^{1} \&$ Serikkazy Kumisbekuly Kumisbekov ${ }^{1}$ \\ ${ }^{1}$ Almaty Academy, Ministry of Internal Affairs of the Republic of Kazakhstan, The Republic of Kazakhstan \\ Correspondence: Serikkazy Kumisbekuly Kumisbekov, Almaty Academy of the Ministry of Internal Affairs of \\ the Republic of Kazakhstan, Utepov Street 29, Almaty, 050060, Kazakhstan. E-mail: skumisbekov@mail.ru
}

Received: February 28, 2015

Accepted: March 20, 2015 Online Published: April 26, 2015

doi:10.5539/res.v7n6p308

URL: http://dx.doi.org/10.5539/res.v7n6p308

\begin{abstract}
The purpose of this article is to analyze the problem of the influence of the Internet on minors. We define the role of the Internet in the development and education of adolescents and young adults. We characterized the psychological characteristics of minors' communicate in the Internet. We discuss the impact of globalization on different cyber-deviation's manifestations in adolescents. A particular attention is paid to information security of children in terms of the development of the information society in modern Kazakhstan. We consider the ways of counteraction the negative effects of the new informational environment. We give recommendations for the prevention of the negative impact of the Internet on minors.
\end{abstract}

Keywords: minors, Internet, information security, prevention, socialization

\section{Introduction}

One of the most important processes in modern Kazakhstan is the transition to an information society. Informatization and computerization of modern society are becoming more and more global.

Internet technology has the greatest importance and prevalence; it connected people across the globe, made communication cheaper and freely and opened new horizons for the world community. Internet in recent years has given man limitless possibilities in the field of transmission, distribution and circulation of information, it allowed you to perform financial and banking transactions, despite the distance and borders.

Internet and social networks have become an integral part of modern society. Every day, millions of people use their services: some are looking for friends, clients, employers or employees, others — simply "kill" their time. The speed of network development is enormous: in 1993 there were only about 70,000 of its users, in 1999_about 200 million, and in 2002 - already 580780 000, which is 9.57\% of the world's population, today this figure has exceeded per billion (How Many Online, 2015) .In 2015, the number of Internet users will grow to 2.89 billion people, which will be $42.2 \%$ of the population of the planet. And by 2018 the network will be used by 3.6 billion, i.e. $48.2 \%$. In many ways, the penetration rate is due to the availability of affordable mobile phones and broadband internet (by the year 2018, 2014).

According to the Institute of Political Solutions, the most demanded in May 2013 in Kazakhstan was the social network "My World" (64.4\% of Internet users), in the second place-"Classmates" (25.9\%), the third-_"Vkontakte" (22.7\%) (Bakytova \& Nurbekova, 2014).

The widespread introduction of information technologies in the life of modern man has both positive and negative consequences. The spread of cyber-deviation in the Internet has become one of the most acute problems of our time. The negative effects of prolonged use of information technology are narrowing the range of interests, escape from reality into the virtual world and the development of dependence.

According to the sociologists' studies, the predominant group of Internet users in Kazakhstan is young people. The younger generation sees the Internet as a basic education and personal communication. So in the words of Prensky (2001), children born after 1980 can be considered as "digital natives", i.e. those who grew up at the same time with the rapid development of digital technologies and cannot imagine a world without computer games, e-mail, Internet, cell phones and instant messaging. At the same time, their parents and teachers are "digital immigrants", who have to rebuild their habitual behaviors, adapting to unfamiliar to them world of new technologies. 
Kazakhstan for a long time has been out of this problem. But the suddenly opened Internet capabilities have absorbed most of the young people. On the one hand, the increase in the number of young internet users, the development of new high-speed communication programs, and virtual interaction, on the other hand - the lack of comprehensive measures, including criminological prevention, this has led to an increase in deviant behavior of youth.

In recent years there has been a dramatic increase in the prevalence of addictive disorders, a variety of their forms, and the emergence of new varieties. Besides the traditionally known addictions in the form of chemical dependence (alcoholism, drug addiction, toxicomania, smoking) we have descriptions of workaholizm, sexual, computer, Internet addiction, and gambling, addictive eating behavior.

According to A. E. Voyskunskiy, it is non-chemical forms of addictions that show almost uncontrolled growth in the youth environment. Such concepts as computer addiction, Internet addiction, gambling, unfortunately, have become a part of our everyday lives (Voiskunsky, 2004).

The emergence of such deviant behaviors is moving into the first place, primarily as a factor of the state's safety. We have to take care of the younger generation, so it will not be exposed to drugs, alcohol, various types of stress, somatic diseases. We should take care about a healthy, strong family, about people involved in the defense of our army, for the weapon should be in the hands of the absolutely normal, healthy people, we should worry about the level of consistency, psychological and mental status of law enforcement officials, because these structures should employ people with cold head and clean hands.

In a broad sense, the mental health of the individual - is the health of the state and is a very important problem that requires a lot of attention.

\section{Method}

Since the topic of criminological research is interdisciplinary, in its development, we relied on the fundamental provisions of criminology, sociology, psychology, philosophy, culturology, pedagogy, theory of law.

In addition, in this work we used such scientific and special methods as a systematic method and the method of comparative study, the statistical method, as well as concrete sociological methods: document analysis, observation.

Reliability and validity of the findings of the study are provided by: the use of a significant number of legislative, monographic, periodical, online sources such as legal, sociological, psychological and criminological, the analysis of statistical data of the Committee on Legal Statistics and Special Records of the General Prosecutor of the Republic of Kazakhstan and prevention programs.

Within the complex criminological research we conducted several independent studies of various aspects of the Internet impact on young people.

As a rule, in criminological researches it is better to use the so-called anonymous survey, when the respondent does not indicate his name and address.

In order to study, what place does Internet take in the daily leisure practice of youth, in 2014 we conducted a sociological survey in three schools and two universities in Alma-Ata on a representative sample $(\mathrm{N}=284)$. As a methodological framework for the collection of primary data we chose the method of mass questionnaire, it is adequate to the task of studying the ordinary life and the interesting behavioral practices. Completed questionnaires were received from 312 respondents aged from 13 to 20 years. Furthermore, to determine the Internet addiction, we conducted an original study using the test proposed by Yang (1996).

\section{Results}

Currently the term "cyber-deviation" appeared in science. As pointed out by Humphrey, without Internet, mobile phones, smart phones and other IT we cannot exist. As a consequence of this are cybercrime and cyber-deviation (Humphrey, 2006).

Analysis of the results of the questionnaire showed that today, virtual and social networks occupy a significant place in the lives of today's youth. This is evidenced by the data obtained as a result of a sociological research. Thus, $95 \%$ of the respondents confirmed that they are active users of social networks. Over $19 \%$ of respondents have 4-5 years of "length of" using on-line communication, $60 \%$ are 2-3 years in the network, and only a year-about $21 \%$. And according to the results of the test made to determine Internet addiction (C. Young) $23 \%$ "live" in the Internet.

There are several hypotheses to explain the reduction in the volume and level of crime. Professor Ya. I. Gilinsky 
raises the following hypothesis, which says that since the late 1990s - early 2000s, around the world there is a tendency to reduce the volume and the level of crime. For example, the homicide rate (per 100 thousand population) in Russia decreased from 23.1 in 2001 to 10.0 in 2013, in the United States from 6.2 in 1998 to 4.7 in 2011, in Germany from 1.2 in 2002 to 0.8 in 2011, in Colombia from 72.2 in 2002 to 33.2 in 2011, in Japan from 0.6 in 2004 to 0, 3 in 2011. Most of the reported crime is "street crime" (street crime) — crimes against life, health, sexual integrity, ownership. Basic subjects of "street crime"- are youth and young adults who in recent decades "left" to the virtual world of the Internet. There they have meetings, love, make friends, hate, shoot, kill, cheat, commit fraud, etc., satisfying - consciously or not - the need for self-assertion, self-realization (Gilinsky, 2014).

According to the research of sociologists, during their leisure time young people put communication on the Internet in the first place. This suggests that young people are realizing that virtual communication cannot replace the real, continue to spend long time staying in the network.

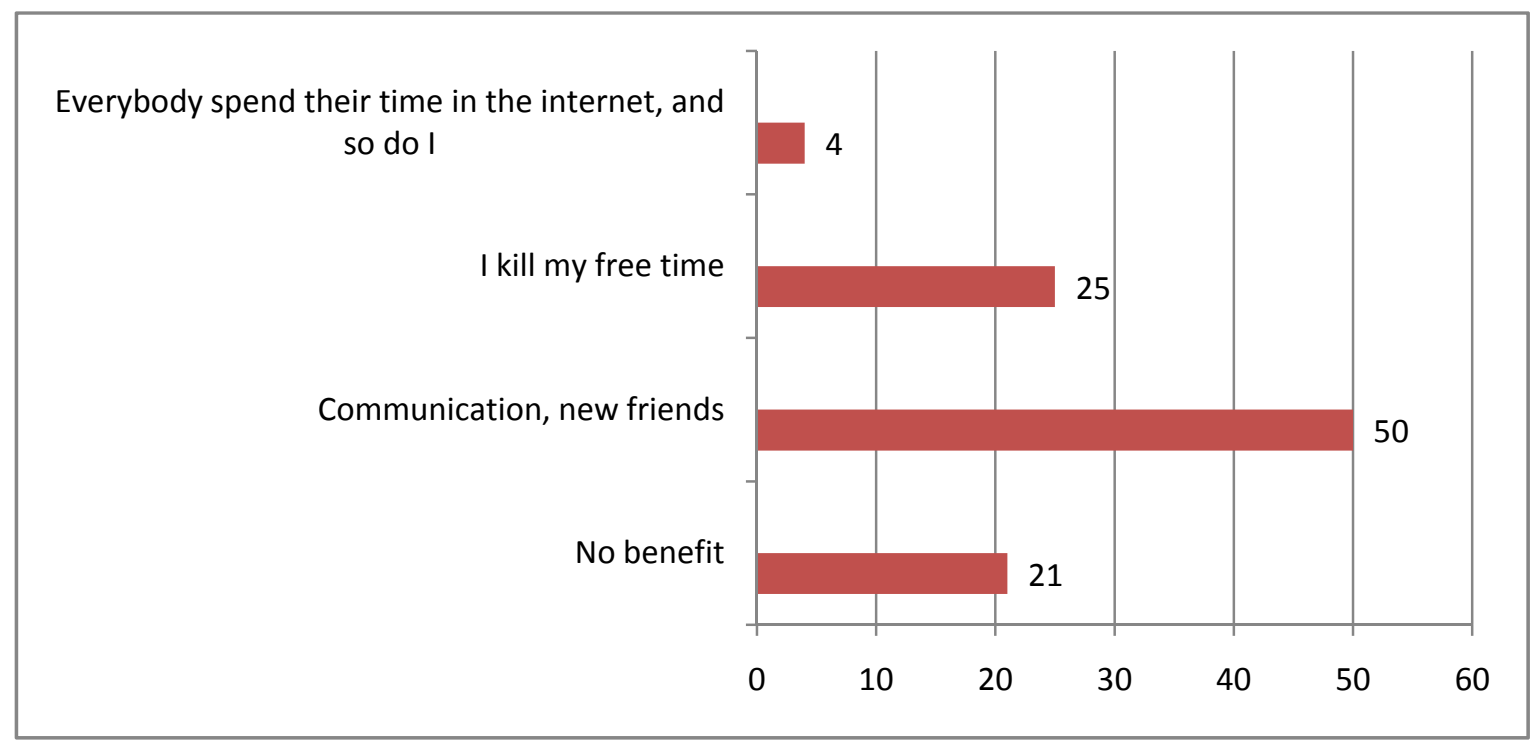

Figure 1. In your opinion, what are the benefits of social networks? (Maulsharif, 2011)

Figure 1 shows that the Internet today is closely linked with the life of young people. Virtual communication not only fills the entire space of youth, but is also considered as a useful exercise. The biggest benefit that they receive from social networks - is communication, so were $50 \%$ of the respondents answer. The majority of young people do not discuss anything serious in the network, they just chatter with friends, acquaintances. $25 \%$ of respondents see the usefulness of social networks for themselves as to "kill" free time. And only $21 \%$ of respondents admit that there is no benefit from this type of entertainment. These results prove once again that social networks are necessary for young people just for fun and simple communication on frivolous topics.

However, today's transformation of the media changes the scope and degree of the criminal influence, which is especially due to the appearance of the Internet. According to the survey of "Kaspersky Lab", of all the sites labeled $18+$, the greatest interest by Russian children is paid to erotic and pornographic sites $-46.4 \%$, followed by the weapon subjects-26.4\%, the third - obscene language-10.7\%. (Information threats on the Internet and children, 2014).

\subsection{Internet Addiction}

Currently we intensively discuss and study the phenomenon (disease, syndrome) "Internet addiction". Internet addiction is defined as "non-chemical dependence on the use of the Internet" (Griffits, 1996). Internet addiction manifests itself in the fact that people prefer life in the Internet, so that they actually begin to abandon their "real" life, spending up to 18 hours a day in a virtual reality.

Kimberly Young gives 4 symptoms of Internet addiction:

1) A compulsive craving to check the e-mail. 
2) Constant expectation of the next access to the Internet.

3) Complaints of the surrounding people on the fact that the person spends too much time in the Internet.

4) Complaints of the surrounding people on the fact that a person spends too much money on the internet (Internet addiction, 2007).

Internet addiction is often understood as much broader. These include: dependence on the computer, i.e. passion for working with a computer (games, programming or other activities); "Information overload", i.e. compulsive (from Eng .compulsive-insurmountable) navigate on the WWW, search in the remote databases; compulsive use of the Internet, i.e., pathological affection to gambling, online auctions or electronic shopping in the Internet; dependence on "cyber-relationships" i.e. on the social uses of the Internet-to communicate in chat rooms, newsgroups and group games, which can ultimately lead to the replacement of the existing in real life, family and friends, with virtual ones; dependency "cybersex" i.e. from pornographic sites on the Internet, from discussing sexual issues in chat rooms or special newsgroups "for adults".

There are features of Internet addiction - it is non chemical addiction, i.e. it does not lead to the destruction of the body, on its effects on the body it is closer to gambling addiction, etc. It is noted that it takes years for the formation of traditional types of addiction, but for Internet addiction, this period is dramatically reduced: according to $\mathrm{K}$. Yang, 25\% of addicts have acquired dependence in six months after they started working in the Internet, $58 \%$-in the second half, and 17\% - soon after a year (Young, 2000).

Many people like computer games, ranging from 4-5 years and older. There is a problem of "hanging-up" in the virtual world, where a child cannot tear himself away from the screen even for a few hours. This limits the interaction of the child with people; he loses communication skills, which are necessary for a normal mental and social development of the child.

Scientists have proved that large doses of computer games lead to the accumulation of chronic stress with all negative consequences for the child. As a rule, aggressive reactions are most pronounced in adolescents, but they appeared and were fixed in the early childhood. Even younger students tend to imitate the so-called anti-social characters from films, video and television, a computer character, whose aggression is usually rewarded, and appears in a favorable light. Children tend not only to identify themselves with particular victims or aggressors, but also to transfer these roles in real-life situations. In addition, the child may become insensitive to brutality and cruelty after watching many scenes of violence.

We believe that media violence has a psychological traumatic impact, it leads to deformation of moral and legal consciousness induces an aggressive and antisocial behavior.

It is well known that computer addiction is one of the serious psychological problems of the younger generation, it lead children and teenagers to alienation from the real life of the society, to cynicism and aggression, to spiritual emptiness.

Studying the nature of human aggression, carried out, in particular, in the works of Erich Fromm leads to the conclusion of a special role of juvenile age in the development of the personality. In this period the individual is particularly susceptible to aggressive forms of behavior.

In general, children who have experienced any kind of violence, have difficulties in socializing. According to Yu. M. Antonyan, rudeness, cruelty, cynicism, aggressiveness, lack of respect for the feelings of others, inability and unwillingness to control themselves (Antonian, 1975). Therefore it is necessary to regulate the sphere of production and distribution of computer games taking into account age and psychological characteristics of minors' users.

\subsection{Suicide}

Let's now discuss how the Internet affects the suicidal behavior of minors. Suicide can be considered as one of the most extreme forms of deviant behavior, intentional deprivation of your own life.

According to the data of the Committee on Legal Statistics and Special Records of the General Prosecutor of the Republic of Kazakhstan, over the last 10 years in Kazakhstan the number of suicides among young people increased three times. Every year, every 12th teenager aged 15 to 19 years tries to kill himself. In the number of suicides in this age group Kazakhstan is the leader among the CIS countries (Commonwealth of Independent States) (Judge, 2013).

In general, the country still not pays enough attention to the impact of the Internet environment. Our studies suggest that internet sites that promote suicide pose a real danger to young Kazakhs. In real life, the child is hard to find someone with whom he can talk about suicide. Now parents spend much time at work. But it happens that 
children have nowhere to go with their problems, and they find support in the Internet. Then he goes to a site or a popular social network and begins to discuss his intentions with like-minded people. He receives support, someone offers to be a partner in suicide, and someone offers more effective methods of suicide. Then intentions turn into actions.

We would remind you that in Kazakhstan several cases of suicide among juveniles were associated with social networks. For example, in May 2013, two teenagers jumped from the 12th floor of high-rise building in Alma-Ata. Later their friends reported that they were active participants of an online group of suicides (about the sites for suicides, 2015). In Alma-Ata a ninth-grade girl, jumped from the fifth floor of an apartment house, before her death, writings and reposts from different groups of suicidal nature began to appear on her personal page in the Internet (Suicidal sites, 2013) .In Pavlodar, the suicide of 12-year-old schoolboy was related to his excessive passion for computer games (12-year-old schoolboy, 2013).

It was revealed that another popular activity of children and adolescents in social networks-is sorting out relations. Partial anonymity and the sense of impunity, which are inspired by the Internet, loosen their tongue. To insult and humiliate on Facebook and VKontakte is much easier than in real life-here it is hard to get a "hit back".

The phenomenon of a mass persecution of one person by his peers (most often - classmates) even got its special name- - "Cyber-bullying". Now this phenomenon and its consequences are being seriously studied by psychology, as in recent years it does not occur in isolated cases, but in mass. And the consequences of such a virtual bullying can be very sad: from tough fights in real life to suicide of the victim.

In our opinion, teenagers are increasingly subjected to psychological pressure on social networks. In a virtual environment there is also a so-called "bullying"-bringing a child to suicide by psychological violence. According to the statistics, each year more than a hundred people in the world commits suicide, this was caused by correspondence or persecution on social networks. For example, in Aktobe, 17-year-old girl died after an incident, when a group in "vkontakte" called "Chicken Aktobe" posted her photo. Under the photo they indicated that she does not only have an active sexual life, but also infects her partners with sexually transmitted diseases (group in "VKontakte", 2014). 17-year-old world champion in karate after bullying in social networks committed a suicide (Champion of Russia, 2014) .In connection with a series of suicides of minors, committed because of insults or threats, done using a variety of online services, in the United States they discuss the possibility of introducing a criminal responsibility for cyber bullying and cyber stalking, to prevent the tragic consequences (Kosenko \& Cherniy, 2012).

However, it is well-known that long-term use of social networks has a negative impact on the psyche, and firstly it concerns young people. It is a well known case when one of the users of Facebook, a resident of Serbia Snezana Pavlovic, got into a psychiatric hospital with a disorder after the fact that her article did not cause enough attention. After that, the doctors even generated a term "syndrome of Snezana", which means stress caused by dissatisfaction of social needs of the individual in the modern world ("Snezana Syndrome", 2011).

Recently, with the appearance of smart phones SELF have gained a great popularity (Eng. "SELF" from "self"-he, himself) - a kind of self-portrait, which consists in imprinting yourself on camera. The increase of "SELF"-is a special case of social-media narcissism and virtual network exhibitionism. For people from the virtual life it is more difficult to build personal relationships, to forgive themselves for shortcomings and to be happy for the success of others.

Of particular concern is the impact of SELF on suicide. American Psychiatric Association reported the emergence of a new disease - "a syndrome of SELF." If the "syndrome of SELF "will not be fought—soon there will be disagreeable feelings of "escaping life," the person's envy to more successful friends and dissatisfaction with him will grow. It is very close to depression and even suicidal tendencies.

There are many examples of that dependence on SELF will lead to suicide. For example, for a successful photo, 19-year-old resident of Newcastle abandoned his study and did not leave his house for six months. During this time, Denny Bowman has lost $13 \mathrm{~kg}$., and nearly killed himself. For a successful picture he photographed himself on a mobile phone for a dozen times a day. During the six months of seclusion Bowman became thin and haggard, his nerves were on edge, and one day, being in despair, the young man decided to die. He was saved by his mother (Dependence on SELF, 2013).

In our opinion, traction to death is due to modern life, stress, information load and in addition to this a difficulty in maintaining contact between parents and children. Now it is a new generation of young parents, who are already covered by current trends, they educate the next generation of teenagers. Researches in this area are also 
an important theoretical material, and may contribute to the study of deviant behavior.

\section{Discussion}

From the moment of birth and throughout life, or some aspect of personality constantly develop. The process of personality formation continues almost during the whole life, with varying degrees of intensity.

The most intensively the person is formed up to 18 years. Since the age of majority, he assimilates knowledge and rules of behavior in the society. The UN Convention "On the Rights of the Child" defines any person under the age of 18 as a child. The current law of the Republic of Kazakhstan dated August 8, 2002 "On the Rights of the Child in the Republic of Kazakhstan" defines a child under the age of 14 years as a juvenile, and from 14 to 18 years as a minor.

The role of the media as a mean of socialization increases even in times of radical changes in the life of the society. The scientist William concluded that media, and particularly television can play a very important and vital role in the process of learning from a very early age (Williams, 1981). The formation of social behavior, value orientations, moral and volitional qualities of the personality, psychological characteristics is predetermined by a new cultural environment, by an incessant flow of information, which sometimes changes the traditional notions of morality, moral behavior, relationships' culture, love, which dominated in the civilized world for centuries. Internet speeds up the development of the child, he gets acquainted with cultural values, but along with it, it often promotes anti-social norms, criminal behavior, borrowed from the negative TV characters, sites on the Internet. Internet plays a very important role for self-identity of the personality, in the search for his own identity, the attempt to comprehend his existence and to find his place in the world.

As we know, the individual is affected by 6 channels of macro environment (demographic, economic, technical-ecological, environmental, natural, political, cultural environment) and three channel of micro environment (parents, friends and media).

We should agree with A. M. Yakovlev, who argues that "social values, norms of behavior, tastes, views, preferences, their perception and condition is the result and the content of the process of human's socialization. Crime is associated with deficiencies in the process of socialization" (Yakovlev, 1971).

Psychologists, educators, sociologists are actively studying the role of the Internet in shaping the personality; they have successfully solved many problems. Overall, the findings of the scientists add up to is that Internet for young people replaces live communication, and is one of the main ways of avoiding daily problems. So, S. L. Talanov rightly notes that "social networks - are not only an ability to make new friends and maintain the existing relationships. It is - one of the ways to escape from reality (the real problems) (Talanov, 2011).

Pupils of the XXI century often get their information through the Internet, which became a modern social institution, and it affects the attitudes, values and behavior of the younger generation.

In the situation of a lack of parental attention, on account of the fact that the modern school, which is in a situation of continuing reforms, actually resigned from the obligation to be one of the main institutions of education, many older students have no choice but to socialize "outside" or to communicate and look for self-realization and self-actualization in the Internet space, which has become an actual environment of his life. For many young people the Internet is more important than books, television, and radio. Accordingly, it is necessary to pass socially important values through the Internet, to protect our children from sites containing scenes of violence, and promoting drug use.

The process of infantilization of the society is observed in the information sphere. Parents lose control over information that is consumed by their children. Thus, the role of the tutor is taken on by the information space.

Parents often think that it's better for their child to spend his time in the Internet than "hanging around" in the basements and entrances. According to K. Yu. Galkin, social factors that contribute to the development of a virtual addiction firstly include public acceptance ("Better computer than drugs") (Galkin, 2009).

The man - is a social creature. Even when working remotely, no one can live in the Internet. With all the desire of each of us to individualization, we cannot exist outside of the society, and for this we need to gain experience of social communication. The child in the future will have to raise a family, to build relationships in the society, not only with socialized people, but with the junkie-neighbor, with a hooligan in the yard, and give them a fight back. Parents who are "saving" their child from the street using the computer, probably, wish him good, but in fact they retard his emotional development. And experience shows that it is the emotional sphere that largely promotes a successful socialization.

The conducted analysis led to the following conclusion: Internet plays a very important role for the 
self-determination of the individual, as well as virtual communication and time wasting in social networks is the main preferences of the leisure of young people. The value of spiritual communion is lost. Most young people become addicted. They can several times a day enter the social networks and sit there for hours.

\section{Conclusion}

The work on this subject reveals guidelines for the development of the Internet and their interaction with teenagers, and their impact on the development, education and socialization of minors. Recently there is an increasing tendency to turn the Internet into a sphere of self-realization. The development of electronic systems has given rise to an entirely new kind of communication and self-realization-human's participation in the interaction with certain partners interesting for him, for whatever reasons, which allows him to find like-minded people and to express himself in communicating with them.

We pay attention to some of some problems associated with the formation of the personality of minors under the influence of the Internet. According to some experts, the cause of many crimes committed by minors is violence on the screen. Aggression on the screen is not metered. For adolescents, there is no barrier between reality and fiction. Watching scenes of aggression leads not only to aggressive behavior, but also to an emotional "rigidity". The child becomes less responsive, cold, he becomes less worried in someone else's pain and suffering. The lack of the necessary legal norms in legislation, which restrict the demonstration of violence, cruelty, pornography leads to an addiction to violence among youth.

A particular attention should be paid to the development of communicative qualities, the ability to resolve conflicts and make decisions, to improve self-esteem of the person, ways of rejecting unacceptable proposals of peers and presenting information about the dangers of long-term using of the Internet.

The following is relevant:

- At the present stage of development of the society, Internet plays a key role in the formation of the personality of the juvenile;

- Besides the family and school, the informational environment becomes the most important factor of socialization. In the future, its role will rapidly increase. Therefore, in the structure of training teachers of a new generation it is necessary to consider the issues related to the provision of informational-psychological, informational - criminological and spiritual-moral safety of the younger generation. In our opinion, in the learning process we should introduce a new subject-"Media pedagogy." The aim of the new object should be teaching students the technologies of secure existence in the increasingly complicating information environment, by countering information threats, facilities of informational environment for the benefit of the harmonious development of the individual and society;

- The rates of the development of Internet in Kazakhstan are far ahead of the process of creating and improving of the relevant normative legal base, which regulates the relations in the network. It is important to emphasize the need to attract public attention to the problem of the development of Internet legislation. Such an experience of creating ethical and legal mechanisms is already available in other countries: "Code of behavior in the Internet" (Canada), "The Charter of the Internet" (France), and "Law on the family access to the Internet" (USA). Therefore, we need a law of the Republic of Kazakhstan "On protecting children from information that is harmful to their health and development", which will create an effective mechanism to ensure the child's right to information security;

- Everywhere and regularly conduct educational work with adults on the security of information, as they have to protect children from criminogenic information;

- Any web site can be used as a mean for the prevention of suicide. At such sites psychologists must work anonymously, and we also need to involve parents who lost a child as a result of suicide.

In conclusion, I want to say about a possible perspective on this subject researches will continue, since $45 \%$ of the population lives in countryside, and studies were carried out only in a city with a large population.

\section{References}

"Snezana Syndrome." (2011, June 6). Traps of social networks. Retrieved January 14, 2015, from http://www.liveinternet.ru/journalshowcomments.php?categ=1\&go=next\&journalid=4393972\&jpostid=169 783738

12-year-old student hanged himself on a belt of a kimono in Pavlodar. (2013, September 5). Retrieved January 10, 2015, from http://www.tengrinews.kz/events/12-letniy-shkolnik-povesilsya-na-poyaseot-kimono-v-pavlodare-241106/ 
Antonian, Y. (1975). The social environment and the formation of the criminal's personality (p. 40). Moscow.

Bakytova, A., \& Nurbekova, J. (2014). Statuses as indicators of the demand for information in social networks with domestic segment of users. Bulletin of the KNU, A series of psychology and sociology, 107-119.

By 2018, the Internet will be used by almost 50\% of the world's population. (2014). Retrieved January 11, 2015, from http://www.geektimes.ru/post/241780/

Dependence on SELF brought a young Man to suicide! (2013, March 25). Retrieved January 18, 2015, from http://www.rus.tvnet.lv/wo_men/zdorovje/253478-zavisimost_ot_sjelfi_dovjela_parnja_do_suicida

Expert: Children suicides-A direct consequence of the Kazakh mentality. (2013, May 5). Retrieved January 12, 2015, from http://www.news.nur.kz/263861.html

Galkin, K. (2009, January 1). Dependence on virtual reality of the computer-A new kind of addictive behavior. Retrieved January 18, 2015, from http://www.psyinst.ru/library.php?part=article\&id=1564

Gilinsky, J. (2014). Deviance of youth in the global world. Retrieved from http://www.crimpravo.ru/ blog/3216.html\#cut

Group in "VKontakte" called "Chicken Aktobe" brought to the death a 17-years-old girl. (2014, October 24). Retrieved January 12, 2015, from http://www.tengrinews.kz/events/gruppa-v-vkontakte-kuritsyi -aktobe-dovela-do-smerti-17-letnyuyu-devushku-263962/

How Many Online. (n.d.). Retrieved from http://www.nua.ie/surveys/how many online/word.html

Humphrey, J. (2006). Deviant Behavior (pp. 272-295). NJ: Prentice Hall.

Information threats on the Internet and children. (2014). Retrieved January 11, 2015, from http://www.bizhit.ru/index/informacionnye_ugrozy_v_internete_i_deti/0-457

Internet addiction. (2007). Guide in addictology. Retrieved January 11, 2015, from http://www.psi-test.ru/pub/i-zavisimost.html

It was offered to talk about the site for suicides in the schools of Kazakhstan. (2015, January 2). Retrieved from http://www.tengrinews.kz/kazakhstan_news/o-saytah-dlya-samoubiyts-predlojili-rasskazyivat-v-shkolah-ka zakhstana-236154

Kosenko, A., \& Cherniy, G. (2012). General characteristics of the psychology of a cyber criminal. Criminological journal of Baikal State University of Economics and Law, 3, 87-94.

Maulsharif, M. (2011). The role of social networks in leisure practice of students. Bulletin of the KNU, A series of psychology and sociology, 4(39), 103-107.

Prensky, M. (2001). Digital Natives, Digital Immigrants, Do They Really Thinking Differently? On the Horizon, $9(5)$.

Russian champion in karate jumped from the 16th floor in Novosibirsk in retaliation to the coach and ex-boyfriend? (2014, August 27). Retrieved January 15, 2015, from http://www.nsk.kp.ru/daily/26275.4/3152210/

Suicidal sites were taken on the control of the Prosecutor General of Kazakhstan. (2013, September 9). Retrieved January 2, 2015, from http://www.tengrinews.kz/kazakhstan_news/suitsidalnyie-saytyi -vzyala-pod-kontrol-genprokuratura-kazahstana-241341/

Talanov, S. (2011). Social networks and personal development. In Bulletin of the higher school (pp. 23-25). Almamater.

Voiskunsky, A. (2004). Actual problems of Internet addiction. Psychological Journal, 1, 35-41.

Williams, T. (1981). How and what do children learn from television? Human Communication Research, 7 , 180-190.

Yakovlev, A. (1971). Crime and Social Psychology (p. 35, p. 140). Moscow: Legal-literature.

Yang, K. (2000). Diagnosis-Internet addiction Internet World (Vol 2, pp. 24-29). 


\section{Copyrights}

Copyright for this article is retained by the author(s), with first publication rights granted to the journal.

This is an open-access article distributed under the terms and conditions of the Creative Commons Attribution license (http://creativecommons.org/licenses/by/3.0/). 